\title{
Analisis Kebutuhan Pendidikan Pencegahan Perilaku Berisiko pada Remaja di Kabupaten Magelang
}

\author{
Fina Idamatus Silmi ${ }^{1}$, Zahroh Shaluhiyah ${ }^{2}$, Priyadi Nugraha Prabamukti ${ }^{2}$ \\ ${ }^{1}$ Puskesmas Mungkid Dinas Kesehatan Kabupaten Magelang \\ ${ }^{2}$ Fakultas Kesehatan Masyarakat Universitas Diponegoro
}

\section{ABSTRACT}

Background: Adolescents are vulnerable to risky behaviors such as smoking, alcohol consumption, and risky sexual behavior. The involvement of one risky behavior can lead to other risky behaviors. Therefore, it is necessary to prevent risky behavior to ensure adolescents' health. This study aimed to prevent risky behaviors according to adolescents' needs.

Method: This was an observational research with the cross-sectional method. Data were obtained using a questionnaire through interviews with respondents. The research subjects were adolescents aged 15-24 years. Samples were randomly selected, as much as 100 adolescents.

Results: There were 2 categories of adolescents, they were "delinquent adolescents" and "ordinary adolescents". The needs of SRH education of two groups were more in contents of SRH, methods, media, time, providers, and venue of SRH information delivery. The majority of respondents mostly preferred to select the subject related to he impact of risky behaviour. Discussion method and mixed media, they like to choose for delivering information at night time. Most of them prefer health workers to be as health educator beside their peers. There was no significant difference in the SRH need between two groups. However, the implementation of risky behavior prevention should be differentiated.
Correspondence

finasilmi123@gmail.com

Article History

Received 7 July 2019

Revised 14 August 2019

Accepted 20 April 2020

Available Online 12 June 2020

Keywords

Need assessment

Adolescents

Risky behavior

Education

Risky behavior

DOI

10.14710./jpki.15.2.51-58

\section{PENDAHULUAN}

Pada umumnya, perilaku-perilaku berisiko yang mengganggu kesehatan seperti merokok, konsumsi minuman beralkohol, maupun perilaku seksual yang berisiko sangat rentan terjadi pada usia remaja. Perilaku berisiko diadopsi oleh para remaja dikarenakan oleh pergaulan yang tidak sehat dan informasi yang tidak terarah. ${ }^{1}$ Di Indonesia sudah terdapat program berbasis remaja, salah satunya yaitu PKPR atau Pelayanan Kesehatan Peduli Remaja yang merupakan program komprehensif untuk mengatasi permasalahan remaja khususnya perilaku berisiko. ${ }^{2}$ Akan tetapi, penyuluhan terkait kesehatan reproduksi pada remaja dinilai kurang memuaskan dari segi materi, metode, media, dan kompetensi petugas penyuluh. ${ }^{3}$ Hasil penelitian tersebut sejalan dengan penelitian lain yang menjelaskan bahwa remaja yang diberikan penyuluhan kesehatan merasa metode penyuluhan maupun pelatihan belum memuaskan. ${ }^{4}$ Menurut pedoman PKPR, salah satu cara yang dapat dilakukan untuk mengatasi permasalahan remaja yaitu melalui KIE (Komunikasi, Informasi, dan Edukasi) yang mana pelaksanaanya harus sesuai dengan kebutuhan para remaja. ${ }^{2}$ Dengan demikian, dapat disimpulkan bahwa sebelum melakukan program terkait remaja seharusnya terlebih dahulu melakukan analisis kebutuhan atau need assessment untuk mengetahui kebutuhan yang diinginkan oleh remaja.

Penelitian tentang analisis kebutuhan pendidikan kesehatan pernah dilakukan Rusady di tahun 2017 dengan judul Analisis Kebutuhan Pendidikan Kesehatan Reproduksi pada Siswa SMP di Wilayah Kecamatan Pedurungan Semarang, yang menilai kebutuhan dari segi materi, metode, media, dan pemberi informasi. ${ }^{5}$ Sementara itu, penelitian tersebut mengukur satu perilaku berisiko kaitannya dengan kesehatan reproduksi. Sedangkan, keterlibatan satu perilaku berisiko dapat memunculkan perilaku berisiko lainnya. Hal tersebut dibuktikan oleh penelitian Mulyandari yang menjelaskan bahwa semakin banyak seseorang terpapar perilaku merokok dan konsumsi minuman beralkohol, maka semakin tinggi pula risiko untuk melakukan hubungan seksual. ${ }^{6}$ Penelitian lainnya juga menyebutkan bahwa perilaku sering/biasa merokok berhubungan dengan perilaku seksual tidak aman pada remaja. Teori problem behavior menyatakan bahwa perilaku remaja cenderung menambah mulai dari sebatas mencoba satu perilaku lalu ke perilaku lainnya. ${ }^{7}$ 
Penelitian terdahulu menjelaskan bahwa pada remaja usia 15-24 tahun yang pernah melakukan hubungan seksual, lebih banyak terjadi pada remaja yang memiliki kebiasaan merokok $(13,1 \%)$ dibandingkan dengan yang tidak merokok (1,8\%). Oleh karena itu, pada remaja yang memiliki kebiasaan merokok, berisiko melakukan hubungan seksual sebesar 8,3 kali. Selain itu, remaja yang pernah melakukan hubungan seksual, lebih banyak terjadi pada remaja yang memiliki kebiasaan minum minuman keras (26\%) dibandingkan dengan yang tidak mengkonsumsi minuman keras (3\%). Dengan demikian, risiko melakukan hubungan seksual sebesar 11,5 kali terjadi pada remaja yang memiliki kebiasaan minum minuman keras. Pada perilaku mengkonsumsi minuman keras, proporsi lebih banyak terjadi pada remaja yang berperilaku merokok $(25,2 \%)$ dibanding yang tidak merokok $(2,8 \%)$, sehingga risiko untuk minum minuman keras pada remaja yang merokok sebesar 11,8 kali. ${ }^{6}$

Menurut teori Lawrence Green, perilaku seseorang dapat dipengaruhi oleh faktor predisposisi berupa pengetahuan dan sikap serta faktor penguat berupa sikap dan perilaku orang disekitar tak terkecuali teman. ${ }^{8}$ Penelitian Rosidah menyebutkan bahwa religiusitas dan perilaku seksual memiliki korelasi negatif, sehingga semakin tinggi religiusitas seseorang maka semakin rendah perilaku seksual pra-nikahnya. ${ }^{9}$ Selain itu, efikasi diri juga mempengaruhi seseorang untuk menggunakan potensi pada dirinya. ${ }^{10}$ Oleh karena itu keyakinan remaja bahwa dia mampu untuk menghindari perilaku berisiko yang berpengaruh buruk terhadap kesehatan adalah efikasi diri terhadap perilaku berisiko. $^{11}$

Penelitian ini bertujuan untuk menganalisis kebutuhan pendidikan pencegahan perilaku berisiko (merokok, mengkonsumsi minuman keras, seks bebas) pada remaja, dengan harapan dapat memberikan gambaran sebuah program berbasis pemberian informasi (KIE) yang sesuai kebutuhan para remaja, agar mereka mampu menghindari perilaku merokok, minum minuman keras, dan seks bebas. Dengan demikian, upaya pencegahan maupun pengendalian perilaku berisiko pada remaja dapat dilakukan secara bersama-sama mengingat bahwa satu remaja dapat melakukan lebih dari satu jenis perilaku berisiko. Selain itu, analisis kebutuhan pendidikan pencegahan perilaku pada penelitian dilihat berdasarkan kategori remaja menurut tingkat religiusitas, pengetahuan, sikap, sikap teman, self efficacy, maupuan perilaku berisiko yang dilakukan.

\section{METODE}

Desain penelitian ini adalah observasional dengan pendekatan cross-sectional sehingga variabel bebas dan terikatnya diambil pada waktu yang sama. Sampel dalam penelitian ini adalah remaja usia 15-24 tahun yang belum menikah di Desa X Kabupaten Magelang. Sampel dipilih secara random menggunakan microsoft excel dan didapatkan sampel minimal sebanyak 88 orang dari total populasi sebanyak 935 orang melalui penghitungan dengan rumus lemeshow. Sampel yang digunakan dalam penelitian ini digenapkan menjadi 100 orang. Pengumpulan data dilakukan melalui wawancara menggunakan kuesioner yang sebelumnya telah dilakukan uji coba pada 10 remaja di daerah yang berbeda dengan tempat penelitian dengan karakteristik yang sama. Sebelum peneliti menemui responden satu per satu, terlebih dahulu dilakukan uji etik penelitian.

Analisis data multivariat menggunakan analisis $k$ mean cluster. Analisis ini bertujuan untuk mengelompokkan remaja berdasarkan karakteristik maupun variabel yang digunakan. Selain itu, juga dilakukan analisis univariat meliputi distribusi frekuensi terhadap karakteristik responden serta kebutuhan pendidikan pencegahan perilaku berisiko.

\section{HASIL DAN PEMBAHASAN}

Tabel 1 menunjukkan bahwa jumlah remaja delinquent (74\%) lebih tinggi daripada remaja ordinary (26\%). Tabel 2 menunjukkan bahwa pada remaja delinquent lebih banyak responden yang berjenis kelamin laki-laki $(84,7 \%)$ daripada perempuan $(58,5 \%)$. Selain itu, lebih banyak responden dalam kelompok berusia 20-24 tahun $(80 \%)$ daripada kelompok usia 15-19 tahun. Pada kategori remaja delinquent, proporsi meningkat pada pendidikan SMA kebawah dan sebaliknya proporsi remaja ordinary semakin meningkat dengan meningkatnya tingkat pendidikan.

Pada umumnya remaja laki-laki memiliki proporsi lebih tinggi dalam perilaku berisiko (merokok, minum minuman keras, hubungan seksual) dibandingkan remaja perempuan, karena remaja laki-laki cenderung hidup bebas dan lebih mudah keluar rumah untuk mencari kesenangan dibandingkan perempuan. Sedangkan perempuan biasanya lebih banyak mendapatkan pengawasan dari orang tua atau saudara yang lebih tua. ${ }^{6}$ Hal tersebut juga dikarenakan keterpaparan remaja perempuan terhadap perilaku merokok juga lebih rendah dibandingkan remaja laki-laki. ${ }^{6}$ Sementara itu, hasil penelitian Mulyandari menggunakan data Survei Demografi dan Kesehatan Indonesia tahun 2012 menjelaskan bahwa perilaku merokok, mengkonsumsi minuman keras serta hubungan seksual lebih banyak terjadi pada remaja yang berusia 20-24 tahun. Perilaku merokok lebih banyak terjadi pada remaja dengan pendidikan SMA kebawah dibandingkan dengan SMA dan Perguruan Tinggi/Akademi. ${ }^{6}$

Faktor religiusitas dapat menjadi faktor pelindung terhadap terjadinya perilaku berisiko. Hal ini dibuktikan dalam penelitian Rosidah bahwasannya religiusitas memiliki korelasi negatif terhadap perilaku seksual pra-nikah. ${ }^{9}$ Sejalan 
dengan asumsi tersebut, penelitian ini menghasilkan fakta bahwa pada kategori remaja delinquent lebih banyak yang memiliki religiusitas rendah. Sebaliknya, pada remaja ordinary lebih banyak yang memiliki religiusitas tinggi.
Pengetahuan merupakan salah satu faktor terjadinya perilaku merokok, minum minuman keras, dan seks bebas pada remaja. ${ }^{12,14}$ Kaitannya dengan penelitian ini yaitu hasil menunjukkan bahwa pada remaja delinquent lebih banyak responden yang memiliki pengetahuan rendah.

Tabel 1. Frekuensi kategori remaja

\begin{tabular}{lcc}
\multicolumn{1}{c}{ Cluster } & Jumlah Responden $(\mathrm{N})$ & Persentase $(\%)$ \\
\hline Remaja delinquent & 74 & 74 \\
Remaja ordinary & 26 & 26 \\
Total & 100 & 100 \\
\hline
\end{tabular}

Tabel 2. Tabel silang kategori remaja dengan karakteristik

\begin{tabular}{|c|c|c|c|c|c|c|}
\hline \multirow{3}{*}{ Variabel } & \multicolumn{4}{|c|}{ Kategori Remaja } & \multirow{2}{*}{\multicolumn{2}{|c|}{ Total }} \\
\hline & \multicolumn{2}{|c|}{ Delinquent } & \multicolumn{2}{|c|}{ Ordinary } & & \\
\hline & $\mathrm{f}$ & $\%$ & $\mathrm{f}$ & $\%$ & $\mathrm{f}$ & $\%$ \\
\hline \multicolumn{7}{|l|}{ Jenis Kelamin } \\
\hline Laki-laki & 50 & 84,7 & 9 & 15,3 & 59 & 100 \\
\hline Perempuan & 24 & 58,5 & 17 & 41,5 & 41 & 100 \\
\hline \multicolumn{7}{|l|}{ Umur } \\
\hline 15-19 tahun & 46 & 70,8 & 19 & 29,2 & 65 & 100 \\
\hline 20-24 tahun & 28 & 80 & 7 & 20 & 35 & 100 \\
\hline \multicolumn{7}{|l|}{ Pendidikan } \\
\hline Tidak sekolah & 1 & 100 & 0 & 0 & 1 & 100 \\
\hline SD & 14 & 93,3 & 1 & 6,7 & 15 & 100 \\
\hline SMP & 26 & 89,7 & 3 & 10,3 & 29 & 100 \\
\hline SMA & 33 & 64,7 & 18 & 35,3 & 51 & 100 \\
\hline $\mathrm{S} 1$ & 0 & 0 & 4 & 100 & 4 & 100 \\
\hline \multicolumn{7}{|l|}{ Religiusitas } \\
\hline Rendah & 48 & 81,4 & 11 & 18,6 & 59 & 100 \\
\hline Tinggi & 26 & 63,4 & 15 & 36,6 & 41 & 100 \\
\hline \multicolumn{7}{|l|}{ Pengetahuan } \\
\hline Rendah & 50 & 100 & 0 & 0 & 50 & 100 \\
\hline Tinggi & 24 & 48 & 26 & 52 & 50 & 100 \\
\hline \multicolumn{7}{|l|}{ Sikap responden } \\
\hline Kurang permisif & 26 & 66,7 & 13 & 33,3 & 39 & 100 \\
\hline Permisif & 48 & 78,7 & 13 & 21,3 & 61 & 100 \\
\hline \multicolumn{7}{|l|}{ Self Efficacy } \\
\hline Rendah & 42 & 85,7 & 7 & 14,3 & 49 & 100 \\
\hline Tinggi & 32 & 62,7 & 19 & 37,3 & 51 & 100 \\
\hline \multicolumn{7}{|l|}{ Sikap teman } \\
\hline Kurang permisif & 28 & 63,6 & 16 & 36,4 & 44 & 100 \\
\hline Permisif & 46 & 82,1 & 10 & 17,9 & 56 & 100 \\
\hline \multicolumn{7}{|l|}{ Perilaku teman } \\
\hline Kurang berisiko & 28 & 65,1 & 15 & 34,9 & 43 & 100 \\
\hline Berisiko tinggi & 46 & 80,7 & 11 & 19,3 & 57 & 100 \\
\hline \multicolumn{7}{|l|}{ Perilaku responden } \\
\hline Kurang berisiko & 30 & 62,5 & 18 & 37,5 & 48 & 100 \\
\hline Berisiko tinggi & 44 & 84,6 & 8 & 15,4 & 52 & 100 \\
\hline
\end{tabular}


Tabel 3. Hasil analisis kebutuhan pendidikan pencegahan perilaku berisiko

\begin{tabular}{|c|c|c|c|c|c|c|}
\hline \multirow[t]{2}{*}{ No. } & \multirow[t]{2}{*}{ Pertanyaan } & \multirow[t]{2}{*}{ Jawaban } & \multicolumn{2}{|c|}{$\begin{array}{c}\text { Remaja } \\
\text { Delinquent }\end{array}$} & \multicolumn{2}{|c|}{$\begin{array}{l}\text { Remaja } \\
\text { Ordinary }\end{array}$} \\
\hline & & & $\mathrm{f}$ & $\%$ & $\mathrm{f}$ & $\%$ \\
\hline \multirow[t]{8}{*}{1.} & Informasi dibutuhkan & Ciri pubertas & 10 & 13,5 & 0 & 0 \\
\hline & untuk mencegah dari & Organ-organ reproduksi & 6 & 8,1 & 1 & 3,8 \\
\hline & perilaku seks & Macam-macam perilaku seks bebas & 7 & 9,5 & 7 & 26,9 \\
\hline & bebas/seks pra nikah & Risiko penyakit akibat seks bebas & 43 & 58,1 & 22 & 84,6 \\
\hline & & Dampak akibat seks bebas & 41 & 55,4 & 22 & 84,6 \\
\hline & & $\begin{array}{l}\text { Cara mencegah agar tidak ikut } \\
\text { berperilaku seks bebas }\end{array}$ & 6 & 8,1 & 1 & 3,8 \\
\hline & & $\begin{array}{l}\text { Cara menahan keinginan/hasrat } \\
\text { seksual }\end{array}$ & 1 & 1,4 & 0 & 0 \\
\hline & & Cara bergaul yang benar & 1 & 1,4 & 0 & 0 \\
\hline \multirow[t]{6}{*}{2.} & Informasi yang & Bahan-bahan rokok & 7 & 9,5 & 5 & 19,2 \\
\hline & dibutuhkan untuk & Bahaya rokok & 28 & 37,8 & 14 & 53,8 \\
\hline & mencegah perilaku & penyakit akibat merokok & 41 & 55,4 & 24 & 92,3 \\
\hline & merokok & $\begin{array}{l}\text { Cara mencegah agar tidak ikut } \\
\text { merokok }\end{array}$ & 5 & 6,8 & 1 & 3,8 \\
\hline & & Cara berhenti merokok & 1 & 1,4 & 0 & 0 \\
\hline & & $\begin{array}{l}\text { Proses masuknya asap rokok hingga } \\
\text { pengaruhnya pada tubuh }\end{array}$ & 0 & 0 & 1 & 3,8 \\
\hline \multirow[t]{8}{*}{3.} & Informasi yang & Jenis-jenis minuman keras & 4 & 5,4 & 2 & 7,7 \\
\hline & dibutuhkan untuk & Bahan pembuat minuman keras & 6 & 8,1 & 7 & 26,9 \\
\hline & mencegah perilaku & Efek fisik minuman keras & 29 & 39,2 & 12 & 46,2 \\
\hline & mengkonsumsi & Efek psikologis minuman keras & 30 & 40,5 & 13 & 50 \\
\hline & minuman keras & $\begin{array}{l}\text { Dampak minuman keras bagi } \\
\text { kesehatan }\end{array}$ & 49 & 66,2 & 25 & 96,2 \\
\hline & & $\begin{array}{l}\text { Cara mencegah agar tidak ikut } \\
\text { berperilaku minum minuman keras }\end{array}$ & 5 & 6,8 & 0 & 0 \\
\hline & & $\begin{array}{l}\text { Bahaya efek fisik dan psikologis } \\
\text { minuman keras }\end{array}$ & 0 & 0 & 1 & 3,8 \\
\hline & & $\begin{array}{l}\text { Gambaran masa depan yang hancur } \\
\text { karena minuman keras }\end{array}$ & 0 & 0 & 2 & 7,7 \\
\hline \multirow[t]{9}{*}{4.} & Metode yang & Diskusi & 52 & 70,3 & 20 & 76,9 \\
\hline & diinginkan remaja & Brainstorming/curah pendapat & 2 & 2,7 & 4 & 15,4 \\
\hline & & Role play/bermain peran & 6 & 8,1 & 1 & 3,8 \\
\hline & & Small group & 3 & 4,1 & 0 & 0 \\
\hline & & Permainan & 8 & 10,8 & 4 & 15,4 \\
\hline & & Bercerita & 7 & 9,5 & 2 & 7,7 \\
\hline & & Debat & 1 & 1,4 & 1 & 3,8 \\
\hline & & $\begin{array}{l}\text { Mapping keputusan/pohon masalah } \\
\text { untuk mencari masalah }\end{array}$ & 0 & 0 & 1 & 3,8 \\
\hline & & Konseling/bimbingan & 3 & 4,1 & 0 & 0 \\
\hline \multirow[t]{3}{*}{5.} & Waktu yang & Pagi & 24 & 32,4 & 9 & 34,6 \\
\hline & diinginkan & Siang & 17 & 23 & 5 & 19,2 \\
\hline & & Malam & 33 & 44,6 & 12 & 46,2 \\
\hline \multirow[t]{4}{*}{6.} & Durasi yang & 0,5 jam & 5 & 6,8 & 5 & 19,2 \\
\hline & diinginkan & 1 jam & 30 & 40,5 & 10 & 38,5 \\
\hline & & $1,5 \mathrm{jam}$ & 3 & 4,1 & 0 & 0 \\
\hline & & 2 jam & 27 & 36,5 & 7 & 26,9 \\
\hline
\end{tabular}




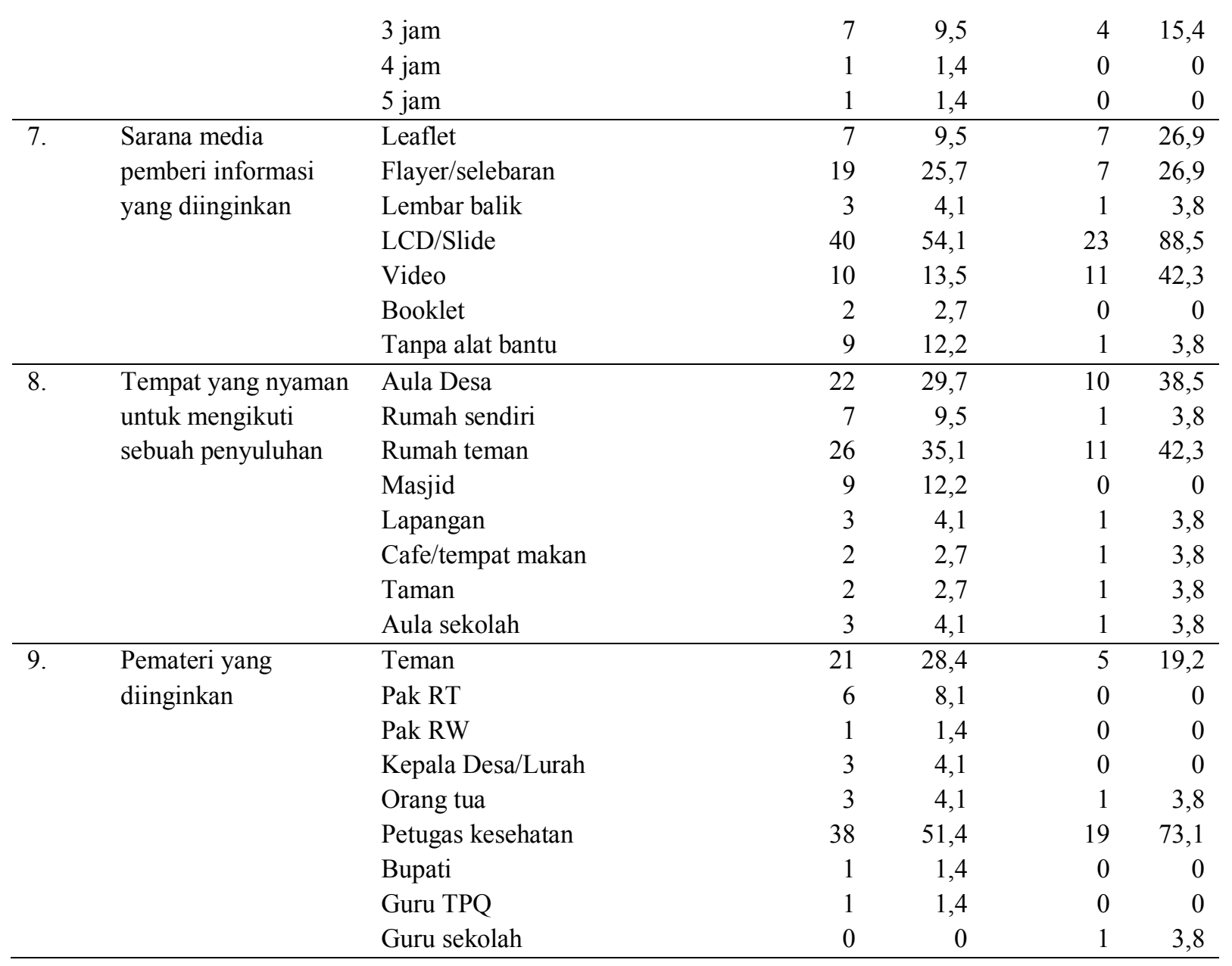

Menurut teori Lawrence Green, perilaku individu dipengaruhi oleh beberapa faktor salah satunya yaitu faktor predisposisi diantaranya berupa sikap. ${ }^{8}$ Sejalan dengan teori tersebut, hasil penelitian menunjukkan bahwa pada remaja delinquent lebih banyak yang memiliki sikap permisif terhadap perilaku berisiko. Sementara itu, faktor reinforcing pada teori L. Green juga menjelaskan bahwa perilaku seseorang dapat dipengaruhi oleh sikap maupun dukungan orang disekitar termasuk teman. ${ }^{8}$ Begitu pula dengan hasil penelitian yang menunjukkan lebih banyak sikap permisif teman sebaya pada kategori remaja delinquent.

Proporsi responden pada kategori remaja delinquent lebih tinggi yang memiliki self efficacy rendah. Kaitannya dengan hasil ini yaitu karena efikasi diri mampu mendorong seseorang untuk dapat menggunakan potensi pada dirinya. ${ }^{10}$ Jadi keyakinan remaja bahwa dia mampu untuk menghindari perilaku berisiko yang berpengaruh buruk terhadap kesehatan adalah efikasi diri terhadap perilaku berisiko. ${ }^{11}$

Salah satu faktor yang mendorong perilaku berisiko seperti merokok, minum minuman keras maupun seks bebas pada remaja dapat berupa pengaruh atau dukungan teman sebaya. ${ }^{12,14}$ Ini menunjukkan bahwa proporsi teman sebaya yang berperilaku berisiko tinggi terdapat pada kategori remaja delinquent.

Adanya fakta bahwa faktor pelindung berupa religiusitas yang rendah ditambah dengan kemampuan remaja untuk mencegah perilaku berisiko juga rendah, sedangkan terdapat faktor risiko berupa pengetahuan rendah, sikap yang permisif, dan lingkungan sosial yang berisiko dapat menjadi alasan mengapa lebih banyak responden pada kategori remaja delinquent yang memiliki perilaku berisiko tinggi.

Berdasarkan tabel 3 diatas dapat diketahui bahwa pada kebutuhan informasi terkait seks bebas pada kategori remaja delinquent dan remaja ordinary sama-sama paling banyak memilih tentang risiko penyakit akibat seks bebas (58,1\% dan 84,6\%). Pada kebutuhan informasi terkait rokok, kedua kategori ramaja paling banyak membutuhkan risiko penyakit akibat merokok (55,4\% dan 92,3\%). Selain itu, informasi terkait minuman keras yang paling kedua kategori remaja yaitu dampak minuman keras bagi kesehatan $(66,2 \%$ dan $96,2 \% \%$ ).

Metode yang paling banyak diinginkan oleh responden pada kategori remaja delinquent dan ordinary yaitu diskusi $(70,3 \%$ dan $76,9 \%)$ dengan alat bantu berupa LCD proyektor $(54,1 \%$ dan $88,5 \%)$. Waktu yang paling 
banyak diminta oleh kedua kategori remaja yaitu di malam hari $(44,6 \%$ dan $46,2 \%)$ dengan durasi pemberian materi selama 1 jam (40,5\% dan 38,5\%). Tempat yang dirasakan nyaman oleh para responden di kedua kategori remaja sebagai tempat penyampaian informasi yaitu rumah teman $(35,1 \%$ dan $42,3 \%)$, serta pemberi materi yang paling diinginkan ada petugas kesehatan $(51,4 \%$ dan $73,1 \%)$.

Kebutuhan informasi terkait seks bebas pada kategori remaja delinquent dan remaja ordinary sama-sama paling banyak memilih tentang risiko penyakit akibat seks bebas. Pada kebutuhan informasi terkait rokok, kedua kategori ramaja paling banyak membutuhkan risiko penyakit akibat merokok. Selain itu, informasi terkait minuman keras yang paling kedua kategori remaja yaitu dampak minuman keras bagi kesehatan.

Theory of Planned Behavior menurut Azjen (1991) mengasumsikan bahwa manusia merupakan makhluk rasional, sehingga menggunakan informasi serta mempertimbangkan tindakan mereka sebelum mereka memutuskan untuk melakukan atau tidak melakukan perilaku tertentu. ${ }^{15}$

Sehingga kaitannya dengan hasil penelitian ini berdasarkan asumsi teori tersebut bahwa kedua kategori remaja ingin mencari alasan untuk mempertimbangkan atau mencegah dirinya terjerumus kedalam perilaku berisiko dengan mengetahui dampak dari tindakan atau perilaku tersebut. Tetapi penelitian ini tidak menggali tentang kebutuhan materi secara spesifik.

Sementara itu, metode yang paling banyak diinginkan oleh responden pada kategori remaja delinquent dan remaja ordinary yaitu diskusi dengan alat bantu berupa LCD proyektor. Hasil penelitian Galingging tahun 2017 menjelaskan bahwa metode yang lebih disukai yaitu diskusi dikarenakan metode ini dapat lebih mengekspresikan diri secara lebih bebas dan mendorong setiap orang didalamnya lebih terbuka dengan adanya anggapan teman satu kelompok lebih mengerti dirinya. Penelitian lain juga menjelaskan bahwa sebuah diskusi membuat anggota kelompok saling berbagi pengalaman sehingga mampu mempengaruhi anggota lainnya. Selain itu, diskusi juga mampu merubah sikap peserta saat proses menyampaikan pendapat. ${ }^{16}$

Pada hasil penelitian ini menunjukkan bahwa waktu yang paling banyak diinginkan oleh kedua kategori remaja yaitu di malam hari dengan durasi pemberian materi selama 1 jam. Jika dilihat dari aktivitas responden yang berusia 15-24 tahun dalam usia produktif baik sebagai pelajar ataupun sebagai pekerja sehingga lebih dipertimbangkan pilihan waktu adalah di malam hari. Sedangkan tempat yang dirasakan nyaman oleh para responden di kedua kategori remaja sebagai tempat penyampaian informasi yaitu rumah teman, serta pemberi materi yang paling diinginkan adalah petugas kesehatan. Hasil ini sesuai dengan penelitian Rusady (2017) yang menyebutkan bahwa penyampaian informasi yang diinginkan remaja pada umumnya yaitu petugas kesehatan. ${ }^{5}$ Penelitian tersebut juga menambahkan bahwa para remaja menginginkan dokter yang masih muda sebagai pemberi materi. Hal itu bisa memberi semangat karena menarik, selain itu mereka bisa bertanya mengenai hal-hal lainnya secara lebih detail dan bersifat medis. ${ }^{5}$

Kebutuhan materi/informasi yang dihasilkan pada penelitian ini masih secara umum (topik materi saja). Sedangkan kedua kategori remaja memiliki karakteristik yang berbeda. Katz Gurevitch dan Haas (dalam kutipan Alexis Tan) mengemukakan bahwa salah satu kebutuhan yang harus dipenuhi yaitu kebutuhan kognitif yang bertujuan untuk memperkuat pengetahuan atau pemahaman serta didasarkan atas keinginan untuk memahami dan menguasai lingkungannya. ${ }^{17}$ Dalam kehidupan sehari-hari dapat dicontohkan seperti rasa ingin tahu akan segala sesuatu yang pernah terjadi, sedang terjadi atau kejadian di masa yang akan datang. ${ }^{18}$ Kaitannya dengan hasil penelitian ini yaitu pada remaja ordinary yang mayoritas kurang berperilaku berisiko bisa jadi membutuhkan materi dampak perilaku berisiko sebagai landasan pemahaman mereka agar mencegah perilaku berisiko di masa yang akan datang. Sedangkan, pada kategori remaja delinquent pada umumnya responden sudah terlanjur berperilaku berisiko. Sehingga dengan pemberian informasi dampak perilaku berisiko saja belum tentu memenuhi kebutuhan mereka. Sebagaimana pendapat Krech, Crutchfield, dan Ballachey bahwa keadaan fisiologis, situasi dan kognisi mempengaruhi timbulnya kebutuhan seseorang. Kebutuhan dapat dirasakan jika terdapat kesenjangan antara harapan dan kenyataan yaitu antara yang seharusnya terjadi dengan kondisi nyata saat ini. ${ }^{19}$ Kondisi yang nyata atau kenyataan saat ini adalah remaja delinquent memiliki perilaku berisiko. Kebiasaan yang sudah terbentuk dapat membuat para remaja delinquent sulit untuk berhenti berperilaku berisiko. Sebagai contohnya, pada perilaku merokok terdapat istilah tobacco dependency (ketergantungan rokok) sehingga perilaku merokok merupakan perilaku yang menyenangkan dan menjadi aktivitas yang bersifat obsesif. Hal ini disebabkan sifat nikotin adalah adiktif, jika dihentikan secara tiba-tiba akan menimbulkan stress. Secara manusiawi, orang cenderung untuk menghindari ketidakseimbangan dan lebih senang mempertahankan apa yang selama ini dirasakan sebagai kenikmatan, sehingga dapat dipahami jika para perokok sulit untuk berhenti merokok. ${ }^{20}$ Dengan demikian, dapat disimpulkan bahwa pada remaja delinquent, remaja tidak hanya membutuhkan informasi secara umum tentang dampak perilaku berisiko. Akan tetapi, juga membutuhkan bantuan yaitu bagaimana cara berhenti dari perilaku berisiko untuk mengurangi risiko dampak yang terjadi maupun cara penanganannya. Menurut WHO dalam Adolescent Friendly Health Service menyatakan bahwa pelayanan kesehatan 
remaja juga harus berperan untuk mendukung remaja mencari jalan atau mengatasi masalah. ${ }^{22}$ WHO juga menyatakan bahwa saat ini remaja kurang memahami gejala atau tingkat risiko yang mereka dapatkan serta tidak mengetahui bahwa pelayanan kesehatan mampu membantu mereka. ${ }^{21}$ Sementara itu, perlu adanya upaya meningkatkan self efficacy pada remaja delinquent untuk meyakinkan bahwa mereka memiliki kemampuan untuk berhenti melakukan perilaku berisiko. Dengan demikian diharapkan adanya peningkatan motivasi serta niat remaja untuk berhenti dan tidak lagi berperilaku berisiko di masa yang akan datang.

\section{SIMPULAN}

Hasil penelitian menunjukkan bahwa pada analisis cluster, didapatkan hasil 2 kelompok remaja yaitu remaja delinquent dan remaja ordinary. Remaja delinquent memiliki ciri-ciri lebih banyak responden yang memiliki religiusitas rendah, pengetahuan rendah, sikap permisif, sikap teman permisif, self efficacy rendah, serta memiliki teman yang berperilaku berisiko, dan responden terkait juga lebih banyak yang berperilaku berisiko. Sifat yang sebaliknya dimiliki oleh kategori remaja ordinary. Pola kebutuhan pada 2 kategori remaja memiliki kesamaan baik pada kebutuhan informasi, metode, media, waktu, tempat maupun pemberi informasi. Pada kebutuhan informasi, kedua kategori remaja paling banyak membutuhkan risiko penyakit akibat perilaku berisiko (merokok, minum minuman keras dan seks bebas). Metode yang diminati oleh responden pada kategori remaja delinquent dan remaja ordinary yaitu diskusi dengan alat bantu berupa LCD proyektor. Sedangkan, waktu yang paling banyak diminta oleh kedua kategori remaja yaitu di malam hari dengan durasi pemberian materi selama 1 jam. Tempat yang dirasakan nyaman oleh para responden di kedua kategori remaja sebagai tempat penyampaian informasi yaitu rumah teman, serta pemberi materi yang paling diinginkan adalah petugas kesehatan. Meskipun kedua kelompok remaja memiliki jenis kebutuhan yang mirip, akan tetapi penanganan dalam upaya pencegahan perilaku berisiko pada remaja ordinary dan remaja delinquent seharusnya dibedakan.

\section{KEPUSTAKAAN}

1. Hidayangsih PS. Perilaku Berisiko dan Permasalahan Kesehatan Reproduksi pada Remaja. J Kesehat Reproduksi. 2014; Volume 5 (2):89-101.

2. Kemenkes RI. Pedoman Standar Nasional Pelayanan Kesehatan Peduli Remaja (PKPR). Jakarta: Kementerian Kesehatan RI; 2014.

3. Rahmadiliyani N, Hasanbasri M, Mediastuti F. Kepuasan siswa SLTA terhadap penyuluhan kesehatan reproduksi remaja oleh Badan Koordinasi Keluarga
Berencana Nasional. Ber Kedokt Masy. 2010;26(4):203-10.

4. Rachmayanti, Rachman IT, Nisman WA. Pelayanan kesehatan peduli remaja menurut perspektif remaja di Kota Magelang. J Kesehat

Reproduksi. 2015;2(1):12-20.

5. Rusady IK, Shaluhiyah Z, Husodo BT. Analisis Kebutuhan Pendidikan Kesehatan Reproduksi Pada Siswa SMP di Wilayah Kecamatan Pedurungan Semarang. J Kesehat Masy [Internet]. 2017;5(5):101020. Available from: https://ejournal3.undip.ac.id/index.php/jkm/article/vie wFile/19229/18256

6. Mulyandari IT, Utomo B. Merokok, Minum Alkohol, dan Hubungan Seksual Pada Remaja: Survei Demografi dan Kesehatan Indonesia Tahun 2012. 2014;

7. Li S, Huang H, Xu G, Cai Y, Huang F, Ye X. Substance use, risky sexual behaviors, and their associations in a Chinese sample of senior high school students. BMC Public Health. 2013;13(1):1.

8. Notoatmodjo S. Promosi Kesehatan dan Perilaku Kesehatan. Jakarta: Rineka Cipta; 2014.

9. Rosidah A. Religiusitas, Hrga Diri dan Perilaku Seksual Pranikah Remaja. J Psikologi. 2012;7(2):58593.

10. Rustika IM. Efikasi Diri: Tinjauan Teori Albert Bandura. Buletin Psikologi. 2012;20 (1-2):18-25.

11. Nasution RD. Hubungan antara Efikasi Diri dengan Perilaku Berisiko terhadap Kesehatan pada Remaja. 2015;3(2):54-67.

12. Pangestu AW, Cahyo K, Kusumawati A. Faktor-faktor yang berhubungan dengan perilaku merokok shisha pada siswa SMA X di Kota Semarang. J Kesehat Masy. 2017;5(1).

13. Zumaroh, Budiati RE. Perilaku Konsumsi Minuman Keras Pada Remaja Di Desa Kunir Kecamatan Keling Kabupaten Jepara. J Keperawatan dan Kesehat Masy [Internet]. 2015;1(4). Available from: http://jurnal.stikescendekiautamakudus.ac.id

14. Nurhayati A, Fajar NA, Yeni. Determinan Perilaku Seksual Pra Nikahpada Remaja SMA Negeri 1 Indralaya Utara. J Ilmu Kesehat Masy. 2017;8(2):8390.

15. Ajzen I. The Theory of Planned Behavior. New York: Organizational Behavior and Human Decision Processes; 1991. 179-211 p.

16. Galinggging. Analisis Kebutuhan Pendidikan Kesehatan Reproduksi dan Seksualitas pada Wanita PUS Muda di Kecamatan Sumowono. Universitas Diponegoro; 2017.

17. Tan A. Mass Communication Theories and Research. Columbus: Ohio Grid Publishing; 1981. 
18. Riani N. Model Perilaku Pencarian Informasi Guna Memenuhi Kebutuhan Informasi (Studi Literatur). Publ Libr Inf Sci. 2017;1(2):14.

19. Krech D, Richard S, Crutchfield, Egerton. Individual in society: a textbook of social psychology. Tokyo: McGraw Hill; 1962.
20. Febriyantoro MT. Pemikiran irasional para perokok. Eksis [Internet]. 2016;XI(2):17. Available from: http://ejournal.stiedewantara.ac

21. World Health Organization. Adolescent Friendly Health Services [Internet]. UK: WHO; 2002. Available from: http://www.who.int/child-adolescent-health 